\title{
Modifikasi Branchless Banking pada Perbankan Syariah di Indonesia Berdasarkan Kearifan Lokal
}

\author{
Fetria Eka Yudiana \\ IAIN Salatiga \\ fetria_belsa@yahoo.com
}

Masuk: 17 April 2018; Diterima: 13 Juni 2018; Terbit: 25 Juni 2018

\begin{abstract}
Sharia banking is a business institution that reflects the existence of sharia economy which is closely related to social life of the community. The purpose of this research is to develop a branchless banking model, by analyzing and designing models based on related literature studies. By using qualitative analysis based on theory and literature study, it can be concluded that the development of branchless banking model in Indonesia especially in sharia banking is more appropriate if it combines technology and local wisdom aspect as it is more suitable with character of cultural diversity, religion and geographical position of Indonesia. Local culture understood by sharia banking can be an advantage in developing branchless banking. Thus Sharia Banking must have the ability to cooperate with local economic units. The design of branchless banking model is integrated, workable and prudent banking sharia, so as to reach more people, especially unbanked people, in accordance with the basic principles of sharia banking in Indonesia.Integrated and in accordance with international standards will be able to increase market share of sharia banking in Indonesia.
\end{abstract}

Keywords: branchless banking; market share; sharia financial inclusion; local wisdom

\begin{abstract}
Abstrak
Perbankan syariah adalah institusi bisnis yang mencerminkan eksistensi ekonomi syariah sangat terkait dengan kehidupan sosial masyarakat. Tujuan penelitian ini adalah mengembangkan sebuah model branchless banking,dengan menganalisis dan mendesain model berdasarkan studi literatur terkait. Dengan menggunakan analisis kualitatif berdasarkan teori dan studi literatur dapat disimpulkan bahwa pengembangan modelbranchless banking di Indonesia terutama pada perbankan syariah lebih tepat jika memadukan teknologi dan aspek kearifan lokal karena lebih sesuai dengan karakter keragaman budaya, agama dan letak geografis Indonesia. Budaya lokal yang dipahami oleh perbankan syariah dapat menjadi keuntungan dalam mengembangkan branchless banking. Sehingga Perbankan syariah harus memiliki kemampuan untuk bekerjasama dengan unit ekonomi lokal. Desain model branchless bankingpada perbankan syariah yang terintegrasi, workable dan prudent, sehingga dapat menjangkau lebih banyak masyarakat terutama unbanked people, sesuai dengan prinsip dasar perbankan syariah di Indonesia, terintegrasi dan sesuai dengan international standard akan dapat meningkatkan market share perbankan syariah di Indonesia
\end{abstract}

Kata Kunci: perbankan tanpa cabang, pangsa pasar, inklusi keuangan syariah, kearifan lokal 


\section{PENDAHULUAN}

Market share adalah indikator untuk menganalisis kekuatan suatu perusahaan atau industri. Meningkatnya market share suatu perusahaan atau industri mengindikasikan bahwa perusahaan tersebut mengalami pertumbuhan yang positif dan efektif. Data hingga bulan Desember 2017, market share perbankan syariah baru mencapai 5.78 persen dari total industri perbankan nasional. Perbankan syariah belum mencapai skala ekonomi, efisiensi minimal dan belum optimal (www.ojk.go.id, 2017). Herman (2015) menyatakan bahwa setidaknya ada tiga alasan mengapa market share perbankan syariah masih rendah yaitu: Pertama, rendahnya literasi perbankan syariah masyarakat tentang perbankan syariah; Kedua, insfrastruktur dan kualitas pelayanan bank syariah masih kurang dibandingkan dengan perbankan konvensional; dan Ketiga, keunggulan non teknis (lebih berpengalaman) bank konvensional dibandingkan dengan bank syariah.

Untuk mempercepat peningkatan market share tersebut, diperlukan terobosanterobosan yang inovatif dari bank syariah sendiri. Salah satunya adalah penggunaan sistem branchless banking. Branchless banking adalah membangun insfrastruktur keuangan yang memungkinkan masyarakat dan dunia bisnis untuk melakukan transaksi pembayaran elektronik setiap hari dari toko-toko retail yang bertindak sebagai agen bank, sehingga mengurangi ketergantungan/kebutuhan akan kantor cabang bank atau insfrastruktur khusus dari bank (Dermish, Kneiding, Leishman, \& Mas, 2012). Program branchless banking dapat berpotensi untuk meningkatkan fungsi bank sebagai lembaga intermediasi karena dapat dijangkau oleh masyarakat kurang mampu dan terpencil (Anand \& Sreenivas, 2013). Dengan branchless banking, bank dapat menjangkau masyarakat yang lebih luas, baik itu secara geografis dan memperluas segmen masyarakat unbanked (Purwati, Fransiska, \& Nugroho, 2014).

Berdasarkan laporan Global Business Guide Indonesia (GBGI) tahun 2014, Indonesia merupakan negara dengan sektor skala microfinance yang besar. Terdapat lebih dari 56.5 juta UMKM yang menyumbang lebih dari 50 persen Gross Domestic Product (GDP). Namun segmen ini tidak mendapatkan cukup akses terhadap layanan keuangan dari bank terutama perbankan syariah untuk permodalan. Di sisi lain, di Indonesia terdapat banyak lembaga keuangan mikro syariah (LKMS) yang bermain di segmen unbanked, seperti Koperasi Simpan Pinjam Syariah (KSPS) yang berbasis komunitas (nelayan, petani, pengrajin, pondok pesantren dan lain-lain) serta Baitul Maal wa Tamwil (BMT) yang merupakan lembaga keuangan khas Indonesia yang berdasarkan syariat Islam. Dalam perkembangannya LKMS belum sepenuhnya mampu melayani segmen unbanked secara baik, karena sebagian besar LKMS juga menghadapi kendala permodalan yang cukup serius (Mujahidin, 2016).

Hal yang sering diabaikan oleh institusi bisnis adalah kurangnya pemahaman terhadap kearifan budaya lokal dimana institusi bisnis itu berada (Mujahidin, 2016). Perbankan syariah merupakan entitas bisnis, sehingga pemahaman tentang kultur masyarakat dan kearifan lokal sangat penting sebagai prasyarat untuk mendesain, menyelaraskan dan mengembangkan bisnis yang dijalankan. Dalam penerapan branchless banking di perbankan syariah seharusnya tidak hanya berorientasi pada profit semata namun juga harus memiliki keselarasan sosio-budaya dan tanggung jawab sosial 
(Santoso \& Ahmad, 2016).

Penelitian Santoso (2015), merekomendasikan bahwa model penerapan branchless banking pada perbankan syariah yang tepat di Indonesia adalah dengan bermitra dengan LKMS sebagai agen untuk dapat menjangkau masyarakat unbanked, karena ada kesamaan prinsip dasar yaitu sesuai dengan maqashid syariah. Karakteristik dasar dan landasan utama antara perbankan syariah dan LKMS adalah sama yaitu prinsip qiradh dan syirkah, serta mengutamakan dakwah (Kartiko, 2015). Pengembangan branchless banking di berbagai negara disesuaikan dengan kondisi, struktur demografi, geografi dan ekonomi di masing-masing negara. Sebagai contoh adalah model branchless banking Safaricom's M-PESA di Kenya. Model ini sangat sukses di negara tersebut dengan menerapkan mobile money service. Penerapan branchless banking juga dapat dengan merekrut agen sebagai kepanjangan tangan bank sehingga setiap hari dapat melayani nasabah dalam transaksi kas (Ivatury, 2006; Lyman, Ivatury, \& Staschen, 2006).

Fokus utama dari pengembangan branchless banking adalah penggunaan teknologi seperti mobile banking. Salah satunya seperti yang diungkapkan oleh Porteous (2006) yang merumuskan branchless banking dalam dua model; (1) Additive models, yaitu memfokuskan pada layanan mobile banking dan internet banking untuk dapat menggunakan jasa layanan perbankan; (2) Transformational models, yaitu dimana yang menjadi target utama model ini adalah unbanked people sehingga membutuhkan saluran yang mudah diakses oleh mereka, seperti penggunaan agen-agen retail untuk dapat memberikan layanan keuangan.

Di Indonesia, penerapan model branchless banking ditetapkan oleh pemerintah melalui Peraturan Otoritas Jasa Keuangan (POJK) No.19/POJK.03.2014. Hal ini sebagai salah satu program pemerintah untuk mewujudkan keuangan inklusif. Momen ini harus dijadikan dasar bagi perbankan syariah untuk menjajaki segmen pasar baru (unbanked people) dan meningkatkan market share. Beberapa penelitian terdahulu seperti yang dilakukan oleh Santoso (2015); Yesi dan Kasmiati (2013); serta Mustafida (2015), sebagian besar berfokus pada analisis kesiapan perbankan syariah menerapkan branchless banking, menganalisis peluang dan tantangan penerapan branchless banking pada perbankan syariah, serta indikator kesiapan perbankan syariah dalam menerapkan branchless banking. Belum ada yang merumuskan dan merekomendasikan model branchless banking pada perbankan syariah.

Mengingat pentingnya isu branchless banking ini serta upaya peningkatan market share perbankan syariah, maka pembahasan pengembangan tentang branchless banking pada perbankan syariah menjadi sangat penting untuk dilakukan. Tulisan ini mencoba untuk menganalisis dan mendesain model branchless banking berdasarkan studi literatur terkait. Diharapkan hasil analisis dan pembahasan tulisan ini bisa mendesain model branchless banking perbankan syariah yang terintegrasi, workable dan prudent, dapat melayani lebih banyak masyarakat terutama unbanked people, sesuai dengan karakter bisnis perbankan syariah, berorientasi masa depan, serta comply dengan standar internasional.

\section{a. Penerapan branchless banking untuk mencapai keuangan inklusif}

Beberapa negara sukses menerapkan model branchless banking dengan dukungan teknologi komunikasi, untuk mencapai keuangan inklusif. Diantaranya adalah Mexico, 
India (Hegde \& Kotian, 2016), Kenya (Kamana, 2014), Afrika (Collings, 2011), dan Tanzania (Nyamtiga, et.al., 2013). Berikut adalah tabel penerapan branchless banking di beberapa negara:

Tabel 1. Pengembangan Keuangan Inklusi dan Branchless Banking di beberapa negara

\begin{tabular}{|c|c|c|}
\hline Negara & Sektor yang terlibat & Implementasi strategi \\
\hline Mexico & $\begin{array}{l}\text { ICT provider, } \\
\text { Lembaga keuangan, } \\
\text { sektor publik }\end{array}$ & $\begin{array}{l}\text { - Bank swasta menawarkan jasa keuangan } \\
\text { mikro kepada masyarakat yang unbanked } \\
\text { - Menggandeng CEMEX sebagai sektor } \\
\text { perusahaan swasta non keuangan untuk } \\
\text { memberikan jasa pelayanan dalam bentuk } \\
\text { tabungan dan kredit bagi masyarakat } \\
\text { miskin dan unbanked. }\end{array}$ \\
\hline India & $\begin{array}{l}\text { - Sektor publik, } \\
\text { - Koperasi, } \\
\text { - Lembaga keuangan } \\
\text { mikro, ICT. }\end{array}$ & $\begin{array}{l}\text { - Sektor publik menyediakan keseluruhan } \\
\text { kerangka kerja, kebijakan keuangan } \\
\text { inklusi diatur dan dikeluarkan oleh bank } \\
\text { sentral }\end{array}$ \\
\hline Kenya dan & - Bank, & - Jasa keuangan mikro dan bank \\
\hline Negara-negara & - ICT provider, & mempromosikan keuangan inklusi \\
\hline $\begin{array}{l}\text { Afrika } \\
\text { (Afrika selatan, } \\
\text { Ghana,Nigeria, } \\
\text { Afrika Utara) }\end{array}$ & $\begin{array}{l}\text { - Sektor publik, } \\
\text { - perusahaan swasta, } \\
\text { - lembaga keuangan } \\
\text { dan non keuangan }\end{array}$ & $\begin{array}{l}\text { - Mempromosikan keuangan inklusi } \\
\text { kepada para pengusaha\& unbanked } \\
\text { - Mengembangkan tekhnologi informasi } \\
\text { untuk mendukung seperti mobile phones, } \\
\text { kartu prabayar dan kedei elektronik }\end{array}$ \\
\hline
\end{tabular}

Sumber: beberapa penelitian terdahulu.

Di Indonesia, penerapan branchless banking masih relatif baru, sehingga penelitian tentang branchless banking masih sangat terbatas. Santoso dan Ahmad (2016) menyimpulkan untuk mengembangkan model branchless banking harus mempertimbangkan nilai-nilai sosial, nilai agama, kepercayaan masyarakat, komunitas, kearifan lokal dan budaya. Sehingga model penerapan branchless banking yang direkomendasikan adalah berbasis komunitas dengan melibatkan beberapa stakeholder seperti Islamic microfinance. Sedangkan Fielnanda (2016) mengungkapkan berdasarkan analytic Network Process BOCR (ANP BOCR), penerapan branchless banking pada bank syariah masih menemui hambatan besar terkait sumber daya manusia, teknologi informasi dan rendahnya tingkat literasi masyarakat terhadap keuangan syariah.

\section{b. Pengaruh Branchless Banking terhadap Market Share}

Salah satu yang mempengaruhi market share perbankan syariah adalah besarnya dana pihak ketiga (DPK). DPK merupakan dana yang dihimpun oleh bank syariah dari masyarakat melalui produk tabungan dan deposito. Sehingga penting bagi bank syariah untuk meningkatkan jumlah DPK dengan jalan memperbanyak dan mempermudah akses bank syariah kepada masyarakat (Purboastuti, Anwar \& Suryahani, 2015). Beberapa penelitian juga telah membuktikan hal tersebut. Seperti yang dilakukan oleh Syeda et al. (2015) di Lahore dimana hasil penelitian tersebut menyarankan pelaksanaan 
branchless banking di negara tersebut, karena dapat meningkatkan akses keuangan masyarakat, sehingga dapat menjangkau masyarakat lebih luas dan dapat meningkatkan jumlah rekening tabungan masyarakat. Sedangkan Disha, Bapat dan Vera (2012), dalam penelitian di India, menyimpulkan bahwa branchless banking dapat meningkatkan keuangan inklusif bagi masyarakat yang berada di daerah terpencil.

Di dalam negeri sendiri, penelitian dari Sarah (2015) tentang dampak branchless banking terhadap kinerja bank Muamalat Indonesia dengan menggunakan indikator kinerja financing to deposite ratio (FDR), capital adequated ratio (CAR), return on asset (ROA) dan Biaya Operasional (BOPO), menunjukkan bahwa kinerja keuangan Bank Muamalat Indonesia dari segi solvabilitas, efisiensi, dan profitabilitas menjadi lebih baik setelah adanya branchless banking.

\section{Keuangan Inklusif}

Leyshon dan Thrift (1995) mendefinikan keuangan inklusif sebagai antitesis dari keuangan eksklusif. Proses keuangan eksklusif membuat masyarakat miskin tidak dapat mengakses benefit dari sektor keuangan dan memberikan kerugian kepada masyarakat untuk mendapatkan akses terhadap sistem keuangan karena kurangnya akses, jaminan, riwayat kredit dan jaringan. Sementara itu dalam Strategi Nasional Keuangan Inklusif (SNKI) keuangan inklusif merupakan kondisi dimana: "hak setiap orang untuk memiliki akses dan layanan penuh dari lembaga keuangan secara tepat waktu, nyaman, informatif, dan terjangkau biayanya, dengan penghormatan penuh kepada harkat dan martabatnya. Layanan keuangan tersedia bagi seluruh segmen masyarakat, dengan perhatian khusus kepada orang miskin, orang miskin produktif, pekerja migrant, dan penduduk di daerah terpencil” (Bank Indonesia, 2014).

Menurut analisis Bank Indonesia (2017) terdapat beberapa faktor yang menyebabkan masyarakat menjadi unbanked, dari sisi supply (penyedia jasa) dan demand (masyarakat), yaitu price barrier (mahal), information barrier (tidak mengetahui), design product barrier (desain produk) dan channel barrier (sarana yang sesuai). Keuangan inklusif memiliki tujuan diantaranya adalah sebagai berikut: (1) Meningkatkan efisiensi ekonomi; (2) Mendukung stabilitas sistem keuangan; (3) Mengurangi shadow banking atau irresponsible finance; (4) Mendukung pendalaman pasar keuangan; (5) Potensi pasar baru bagi perbankan; (5) Meningkatkan Human Development Index (HDI) Indonesia; (6) Berkontribusi positif terhadap pertumbuhan ekonomi dan berkelanjutan; (7) Mengurangi kesenjangan (inequality) dan rigiditas low income trap, sehingga dapat meningkatkan kesejahteraan masyarakat dan menurunkan tingkat kemiskinan. Dengan demikian, keuangan inklusif merupakan strategi nasional untuk mendorong pertumbuhan ekonomi. Salah satu tujuannya adalah memberikan potensi pasar baru bagi perbankan (termasuk perbankan syariah) untuk dapat memperluas serta meningkatkan market share-nya

\section{Branchless Banking}

Branchless banking seperti yang dijelaskan dalam preliminary study Bank Indonesia (2011) merupakan konsep penyediaan layanan perbankan di luar bentuk konvensional bank pada umumnya baik dengan menggunakan layanan teknologi informasi dan teknologi komunikasi (Information, communication and technology/ 
ICT) maupun melalui keterlibatan pihak ketiga (business correspondents). Sedangkan menurut Carmel dan Scott (dalam Purwati et al, 2014), branchless banking sebagai bentuk pelayanan jasa keuangan kepada masyarakat di luar cabang bank yang tradisional dengan menggunakan teknologi informasi dan komunikasi (ICT).

Segmen utama branchless banking, adalah poor and unbanked (low income people) karena traditional bank (memiliki cabang dan infrastruktur secara fisik) menganggap mereka cukup costly untuk diberikan layanan dan produk perbankan. Dalam hal ini teknologi informasi menjadi positioning dan key deferentiator branchless banking.

\section{Model Branchless Banking di Indonesia}

Dalam aplikasi branchless banking terdapat tiga model yang umum digunakan yaitu: (1) bank based model; dan (2) non bank based model;

\section{a. Bank Based Model}

Dalam model ini, penyelenggara layanan adalah bank. Bank menciptakan produk dan jasa keuangan, namun pendistribusian produk dan layanan tersebut dilakukan melalui retail agent yang mengelola semua atau hampir semua interaksi dengan nasabah (Lyman et al, 2006). Bank dalam model ini berperan penuh mulai proses perizinan, operasional, pengelolaan finansial dan sistem keuangan (Wibowo, 2013).

Jenis saluran distribusi yang digunakan dalam model ini melalui retail agent dan mobile banking. Retail agent berinteraksi dengan nasabah dalam menyediakan jasa layanan keuangan. Retail agent melakukan komunikasi langsung dengan bank dengan menggunakan telepon maupun terminal Point of Sale (POS). Ada dua jenis Retail Agent yaitu, (1) Super Agent, yaitu badan hukum yang menjalin kerjasama untuk distribusi layanan keuangan, memiliki jaringan yang luas dan bisnis yang sudah berjalan; (2) Sub Agent, yaitu jaringan dari super agent yang tersebar diseluruh wilayah. Transaksi face to face dengan nasabah akan berlangsung dengan sub agent. Negara Asia yang sukses menggunakan model ini adalah India (Disha et al, 2012).

\section{b. Non-Bank Based Model}

Dalam model ini bank syariah hanya berperan sebagai supporting. Perusahaan telekomunikasi yang bertindak sebagai penyedia jasa layanan perbankan tanpa melibatkan bank syariah. Di Indonesia penerapan hal ini dalam bentuk mobile banking, sebagai sarana penunjang transaksi bagi nasabah yang telah mempunyai rekening.

\section{Kearifan Lokal dan Lembaga Keuangan Mikro Syariah \\ - Teori 'Ashabiyat (Teori Solidaritas Kelompok),}

Sebuah budaya lahir dari keluhuran nilai, kemuliaan sikap dan keagungan tradisi masyarakat yang berjalan secara berkelanjutan dan mengakar. Dalam masyarakat beradab, budaya di bangun atas dasar konsensus nilai-nilai kearifan lokal. Kearifan lokal merupakan norma serta nilai-nilai sosial tentang bagaimana membangun keseimbangan lingkungan alam dengan gaya hidup serta kebutuhan manusia. Budaya dan kearifan lokal harus dikaitkan dengan aktivitas bisnis.

Ciri khas kearifan lokal adalah tingginya tingkat solidaritas terhadap lingkungan. Dalam sosiologi Islam dikenal teori 'Ashabiyat, teori ini merupakan perwujudan teori harmoni $k a$ al-jasad al-wahid yaitu kelaziman saling melindungi, pengembangan potensi, saling mengisi dan membantu diantara sesama manusia. Menurut teori ini 
kehidupan komunitas muslim itu dimisalkan dengan ka al-bunyan yasuddu ba'duhu $b a$ 'dla, bagaikan sebuah bangunan yang satu dengan yang lainnya saling memperkokoh dan memperkuat (Khaldun, 1986).

Teori 'Ashabiyat dan konsep ta'awun al ihsan didasarkan pada pemikiran ajaran Islam yang didalamnya terkandung norma akidah dan syari'at (Syaltut, 1959). Unsur syari'at merupakan norma utama bagi masyarakat muslim, karena didalamnya memuat berbagai aturan, termasuk dalam hal bermuamalah. Akhlak menjadi penekanan perilaku secara umum khususnya dalam kegiatan ekonomi. Pandangan yang menekankan pada kekuatan moral akan berpeluang mengantarkan manusia pada kebahagiaan dan kesejahteraan.

Prinsip keuangan syariah memiliki dimensi dan aplikasi yang luas dalam suatu sistem perekonomian, karena tidak hanya terfokus pada sistem bagi hasil (profit sharing), tetapi juga secara sempurna menanamkan suatu kode etik (moral, sosial dan agama) dalam mempromosikan suatu keadilan dan kesejahteraan. Secara umum lembaga keuangan syariah mengutamakan hubungan kemitraan yang berprinsip pada syariah.

\section{PEMBAHASAN}

Karakteristik finansial unbanked memang sangat kurang memenuhi standar bank, seperti, mereka tidak memiliki penghasilan tetap dan tidak memiliki jaminan usaha, sehingga dianggap terlalu berisiko bagi bank untuk menjangkaunya. Selain itu masyarakat unbanked masih memiliki tingkat literasi yang rendah terhadap keuangan syariah. Di sisi lain, perbankan syariah memiliki keterbatasan cakupan wilayah jaringan kantor, kurangnya informasi mengenai nasabah potensial, serta biaya pendirian kantor cabang yang masih tinggi.

Pengembangan branchless banking perbankan syariah harus meliputi aspek bisnis dan non bisnis. Aspek bisnis adalah dimana pengembangan model harus mendorong pertumbuhan perbankan syariah dan juga market share perbankan syariah. Sedangkan aspek non bisnis atau aspek syariah pengembangam model ini harus mengandung unsur keadilan, kemaslahatan dan keseimbangan guna mencapai masyarakat Indonesia yang lebih sejahtera yang sesuai dengan maqasid al syariah.

Branchless banking merupakan pendekatan yang digunakan perbankan syariah agar dapat menjangkau masyarakat yang unbankable. Branchless banking merupakan program yang dapat memberikan dampak positif bagi perbankan syariah dan juga nasabah, diantaranya penghematan biaya, modal yang relatif sedikit untuk memperluas market share, kemampuan bekerjasama dengan unit ekonomi lokal, kemudahan akses dan pembiayaan sektor produktif mikro (Mustafida, 2015).

\section{Peluang dan Tantangan Penerapan Branchless Banking Perbankan Syariah}

Peraturan Otoritas Jasa Keuangan Nomor 19/POJK.03/2014 tentang Layanan Keuangan Tanpa Kantor dalam Rangka Keuangan Inklusif, disebutkan bahwa lembaga keuangan yang dapat menjadi penyelenggara branchless banking adalah bank dan perusahaan asuransi baik syariah maupun konvensional. Dengan demikian, program branchless banking merupakan peluang emas bagi perbankan syariah untuk menjangkau masyarakat lebih luas. Potensi terbuka lebar mengingat jumlah masyarakat muslim di 
Indonesia mencapai lebih dari $80 \%$ dari total penduduk.

Pengembangan teknologi branchless banking dapat berjalan optimal jika didukung oleh teknologi berbasis internet. OJK mensyaratkan, bank penyelenggara branchless banking harus memiliki insfrastruktur elektronik seperti mobile banking, internet banking atau host to host system (Peraturan OJK No. 19/POJK.03/2014 pasal 10 ayat 1.d). Hal ini menjadi tantangan tersendiri karena belum memadainya infrastruktur terutama daerah luar Jawa yang mana belum semuanya mendapatkan akses yang baik terhadap jaringan telekomunikasi. Kendala sinyal merupakan masalah yang harus dipecahkan oleh penyedia jasa telekomunikasi, Ascarya (2015). Selain itu, keanekaragaman budaya dimana karakteristik masyarakat di pedesaan cenderung suka berkumpul atau bergotong royong, menjadikan penerapan model branchless banking dengan mobile banking kurang sesuai untuk masyarakat ini, Santoso (2015), Blanco et.al (2014), Sankaramuthukumar dan Alamelu (2012).

Dari beberapa peluang dan tantangan tersebut, perbankan syariah harus mengembangkan model branchless banking yang dapat menjangkau masyarakat unbanked yang sesuai dengan karakter mereka sehingga dapat meningkatkan market share-nya.

\section{Alternatif Model Branchless Banking Perbankan Syariah}

Model branchless banking dengan sistem keagenan sebagai mitra merupakan salah satu alternatif yang tepat bagi perbankan syariah. Hal ini dikarenakan karakteristik masyarakat unbanked di Indonesia yang sebagian besar berada di wilayah pedesaan, pesisir, pegunungan dan sebelumnya mereka telah terlebih dahulu mengenal lembaga keuangan mikro syariah yang berbasis komunitas. Santoso dan Ahmad (2016) dalam makalahnya merekomendasikan sebuah model branchless banking pada perbankan syariah yang bermitra dengan koperasi syariah, BMT dan baitul qirad sebagai agen dengan analisis bahwa LKMS ini sudah lama dikenal oleh masyarakat desa, memiliki jaringan yang luas dan berprinsip syariah.

Berikut adalah alternatif model branchless banking perbankan syariah di Indonesia:

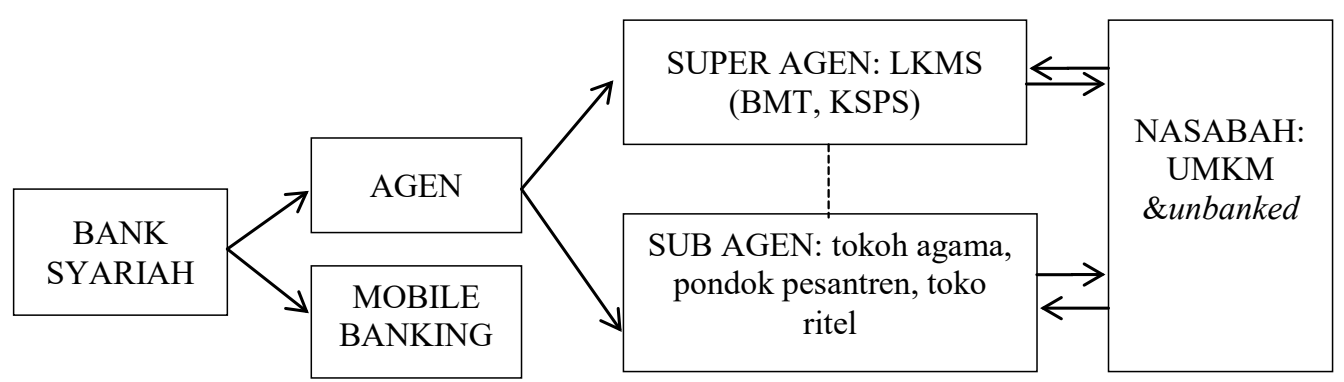

Sumber: Modifikasi model branchless banking dari beberapa referensi

Gambar 1. Modifikasi model Branchless Banking Perbankan Syariah 


\section{Penjelasan model adalah sebagai berikut:}

Branchless banking pada perbankan syariah bertujuan untuk memberikan akses layanan keuangan sektor UMKM dan masyarakat unbanked. Pelayanan terhadap transaksi keuangan, pengiriman uang, menyimpan kelebihan pendapatan, memperoleh tambahan modal usaha produktif atau pembiayaan syariah. Sehingga pengembangan model branchless banking harus sesuai dengan karakteristik segmen yang dituju serta sesuai dengan syariat Islam.

Penulis mengajukan model branchless banking ini didasarkan pada teori harmoni ka al-jasad al-wahid dan teori 'ashabiyat. Dalam kedua teori tersebut ditekankan pada norma/akhlak dalam setiap transaksi ekonomi dan adanya keharusan saling melindungi dan mengembangkan potensi, saling mengisi, saling membantu diantara sesama manusia.

Branchless banking merupakan program untuk menjangkau lapisan unbanked (sesuai dengan tujuan utama perbankan syariah berdasarkan maqasid syariah kesejahteraan bagi masyarakat), sehingga dalam pelaksanaan branchless banking, bank syariah dapat bekerjasama dengan pihak lain yang disebut agen. Agen dikategorikan dalam dua jenis yaitu (1) Super Agen dan (2) Sub Agen. Super Agen merupakan suatu badan hukum yang memiliki jaringan luas dan bisnis yang sudah berjalan. LKMS seperti BMT, KSPS (berbasis komunitas, pondok pesantren) merupakan lembaga yang dapat diajak bekerja sama dengan perbankan syariah. Sedangkan Sub Agen merupakan jaringan/ individu yang memenuhi persyaratan sesuai dengan POJK No. 19/POJK.03/ 2014 dan prinsip syariah tentang rukun dan syarat kerjasama. Transaksi yang terjadi adalah face to face dengan nasabah. Agen merupakan kunci sukses dari model branchless banking (Rijanto, 2016).

Rekomendasi LKMS sebagai agen didasarkan pada kesamaan tujuan dan prinsip dasar syariah, sehingga memudahkan bagi bank syariah untuk menjalin kerjasama. Kerjasama antara bank syariah dan agen harus didasarkan pada akad dan sesuai dengan prinsip syariah. Agen sebagai ujung tombak penerapan branchless banking dapat melakukan pelayanan penyetoran tabungan dan penarikan dana bagi nasabah di desadesa sehingga akan mempermudah layanan transaksi keuangan. Dalam mekanisme ini, perbankan syariah dapat menyalurkan pembiayaan produktif melalui agen yang potensial dan memenuhi kriteria khusus dengan sistem penyaluran pembiayaan yang telah terstandar dengan syarat ringan. Agen dapat direkrut dengan proses seleksi yang ketat untuk menjaga kredibilitas perbankan syariah.

Selama ini segmen UMKM dilayani oleh LKMS yang tersebar sampai ke pelosok desa. Potensi pasar dan peluang ini dapat dimanfaatkan oleh bank syariah, sehingga memerlukan kerjasama dengan LKMS. Bentuk kerjasama keagenan dengan BMT dan koperasi syariah lainnya perlu dikembangkan karena beberapa alasan berikut:

a. Angka pertumbuhan BMT yang sangat pesat mencapai angka 5.200 BMT di tahun 2015 dan mampu melayani nasabah mencapai 10 juta orang.

b. BMT merupakan lembaga keuangan non bank yang berprinsipkan syariah bertujuan menghimpun dan menyalurkan dana disertai imbalan jasa. Lembaga keuangan mikro syariah ini berbasis koperasi dan merupakan lembaga keuangan khas Indonesia yang sesuai kondisi hukum dan kebutuhan pasar.

c. BMT dapat menjadi agen bagi pelaksanaan program branchless banking karena keberadaan BMT dapat menjangkau daerah pedesaan. 


\section{Implikasi Market Share Perbankan Syariah melalui Branchless Banking}

Untuk meningkatkan market share perbankan syariah, branchless banking merupakan salah satu model yang tepat digunakan. Market share pada perbankan syariah dapat ditingkatkan melalui tiga indikator yaitu: (1) bertambahnya jumlah layanan bank syariah; (2) tersedianya produk yang sesuai dengan kebutuhan masyarakat; (3) meningkatnya jumlah rekening serta meningkatnya jumlah dana pihak ketiga (DPK). Market share merupakan indikator yang mampu menjelaskan kemampuan perusahaan dalam menguasai pasar serta posisi perusahaan di pasar persaingan.

Tabel 2. Faktor yang Mempengaruhi Market Share Perbankan Syariah dan Strategi Peningkatannya.

\begin{tabular}{|c|c|c|c|}
\hline Faktor & Indikator & Strategi & Sumber \\
\hline $\begin{array}{l}\text { Dana Pihak } \\
\text { Ketiga (DPK) } \\
\text { (Purboastuti, et al } \\
\text { 2015) }\end{array}$ & $\begin{array}{l}\text { Tingkat } \\
\text { aksestabilitas } \\
\text { (keuangan } \\
\text { inklusif) }\end{array}$ & $\begin{array}{l}\text { Branchless banking dapat } \\
\text { meningkatkan akses layanan } \\
\text { bank oleh unbanked. }\end{array}$ & $\begin{array}{l}\text { Dermish et al. } \\
\text { (2012) }\end{array}$ \\
\hline \multirow[t]{2}{*}{$\begin{array}{l}\text { Jumlah rekening } \\
\text { tabungan yang } \\
\text { aktif (Mas, 2009). }\end{array}$} & $\begin{array}{l}\text { Tingkat literasi } \\
\text { keuangan syariah }\end{array}$ & $\begin{array}{l}\text { Branchless banking } \\
\text { merupakan salah satu strategi } \\
\text { untuk dapat meningkatkan } \\
\text { literasi keuangan syariah } \\
\text { masyarakat unbanked, } \\
\text { karena bank penyelenggaran } \\
\text { branchless banking harus } \\
\text { melakukan edukasi dan } \\
\text { sosialisasi program kepada } \\
\text { masyarakat. }\end{array}$ & $\begin{array}{l}\text { Wibowo } \\
(2013)\end{array}$ \\
\hline & & $\begin{array}{l}\text { Branchless banking dapat } \\
\text { meningkatkan jumlah rekening }\end{array}$ & $\begin{array}{l}\text { Wibowo } \\
(2013), \\
\text { Hegde dan } \\
\text { Kotian }(2016)\end{array}$ \\
\hline $\begin{array}{l}\text { Jumlah transaksi } \\
\text { yang dilakukan } \\
\text { agen }\end{array}$ & $\begin{array}{l}\text { Inovasi produk } \\
\text { dan jaringan } \\
\text { layanan } \\
\text { perbankan } \\
\text { syariah }\end{array}$ & $\begin{array}{l}\text { Branchless banking } \\
\text { merupakan bentuk inovasi } \\
\text { layanan keuangan oleh bank } \\
\text { agar dapat menjangkau } \\
\text { masyarakat unbanked } \\
\text { khususnya yang tinggal di } \\
\text { pedesaan dan daerah terpencil }\end{array}$ & $\begin{array}{l}\text { Data } \\
\text { menunjukan } \\
\text { lebih dari } \\
50 \text { persen } \\
\text { penduduk } \\
\text { Indonesia } \\
\text { tinggal } \\
\text { di daerah } \\
\text { pedesaan. }\end{array}$ \\
\hline
\end{tabular}

Sedangkan potensi perluasan market share dan strategi untuk mencapainya dapat dilihat pada tabel 3 . 
Tabel 3. Potensi Perluasan Market Share Perbankan Syariah di Indonesia

\begin{tabular}{|c|c|c|}
\hline Potensi & $\begin{array}{l}\text { Strategi untuk } \\
\text { mencapainya }\end{array}$ & Keterangan \\
\hline $\begin{array}{l}\text { Jumlah penduduk } \\
\text { Indonesia yang } \\
\text { mayoritas } \\
\text { muslim (kurang } \\
\text { lebih } 80 \text { persen) }\end{array}$ & $\begin{array}{l}\text { Program literasi } \\
\text { nasional serta } \\
\text { program sosialisasi } \\
\text { masing-masing bank } \\
\text { syariah } \\
\text { Program Aku Cinta } \\
\text { keuangan Syariah }\end{array}$ & $\begin{array}{l}\text { Hasil survei World Bank (2016) } \\
\text { menunjukkan bahwa } 32 \text { persen penduduk } \\
\text { Indonesia tidak memiliki tabungan, baik } \\
\text { di lembaga keuangan formal maupun di } \\
\text { lembaga keuangan informal dan dapat } \\
\text { dikelompokkan sebagai financially } \\
\text { excluded dari segi tabungan. Dari segi } \\
\text { pinjaman, hanya } 60 \text { persen penduduk } \\
\text { yang memiliki akses terhadap kredit (yang } \\
\text { terdiri dari } 17 \text { persen penduduk yang } \\
\text { meminjam di lembaga keuangan bank dan } \\
43 \text { persen meminjam di lembaga keuangan } \\
\text { non-bank), sementara sekitar } 40 \text { persen } \\
\text { penduduk Indonesia tidak memiliki akses } \\
\text { terhadap pinjaman (financially excluded } \\
\text { dari sisi kredit). }\end{array}$ \\
\hline
\end{tabular}

Komposisi Program branchless unbanked di banking perbankan Indonesia syariah

Jumlah UMKM di Indonesia

Program Branchless Banking perbankan syariah.

Berdasarkan analisa BCG Matrix untuk pemetaan potensi pembiayaan UMKM di atas, dapat disimpulkan bahwa dengan adanya kebijakan branchless banking, yang memungkinkan bank untuk memberikan layanan keuangan tanpa harus membangun kantor fisik bank melainkan melalui point of service (agen). (Wibowo, 2013).
Berdasarkan hasil survei Bank Dunia, sekitar $79 \%$ masyarakat yang tidak memiliki tabungan dikarenakan tidak memiliki uang. Namun demikian, masyarakat berpendapatan rendah adalah active money managers yang sangat membutuhkan akses keuangan terhadap lembaga keuangan khususnya perbankan.

Data menunjukan ada 56.5 juta UMKM yang memberikan kontribusi lebih dari 57.1 persen terhadap Gross Domestic product (GDP) di 2014. Sebagian besar UMKM tidak memiliki akses terhadap layanan keuangan bank untuk mengembangkan usaha mereka terutama bagi UMKM yang berada di pedesaan (Bank Indonesia, 2016). Potensi pasar kredit UMKM di Indonesia sebesar Rp. 1.500 triliun.

Dari potensi pasar sebesar Rp. 1.500 triliun tersebut, baru sekitar $\mathrm{Rp}$ 281,84 triliun pembiayaan yang telah disalurkan melalui kredit oleh bank umum maupun BPR. Angka ini baru mencakup 18,8 persen dari total potensi yang diperkirakan (Wibowo, 2013). 
Berikut adalah kerangka kerja keuangan inklusif penerapan branchless banking pada perbankan syariah berbasis teknologi dan kearifan lokal:

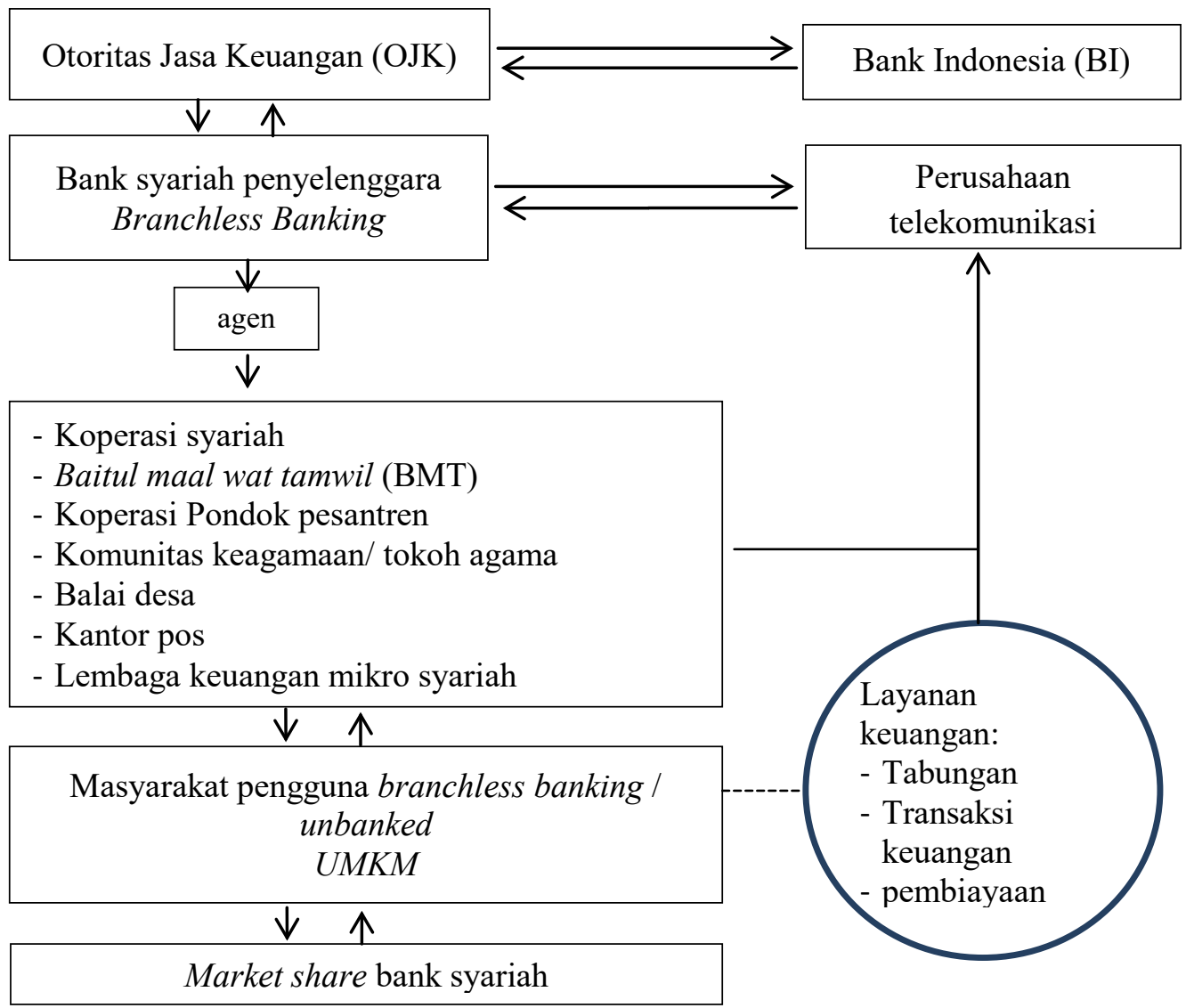

Gambar 2. Kerangka kerja branchless banking pada perbankan syariah dan market share

Kerangka kerja awal dari kebijakan keuangan inklusif dengan penerapan branchless banking di Indonesia adalah adanya regulasi yang berimbang antara inovasi dan perlindungan konsumen. OJK dan Bank Indonesia merupakan institusi yang memiliki kewenangan untuk mengeluarkan regulasi dan melakukan pengawasan terhadap operasional perbankan syariah. POJK No. 19/POJK.03/2014 tentang layanan keuangan tanpa kantor dalam rangka keuangan inklusif yang tertera dalam pasal 2 ayat 1 dan 2 yang berbunyi (1) setiap lembaga jasa keuangan bertanggung jawab untuk mendukung terwujudnya keuangan inklusif; (2) dalam rangka mendukung keuangan inklusif sebagaimana dimaksud pada ayat (1) lembaga jasa keuangan dapat menjadi penyelenggara branchless banking.

Dalam penerapan branchless banking, mutlak disyaratkan adanya infrastruktur teknologi informasi yang dapat terkoneksi dengan perbankan syariah dan berbagai sistem pembayaran. Agen dan sub agen yang bertindak sebagai unit perantara layanan keuangan (UPLK) akan dilengkapi dengan alat pencatat transaksi seperti mesin EDC, point of sales (POS) atau telepon genggam. Konsep branchless banking melakukan 
banyak penyederhanaan dalam layanan, namun prinsip kehati-hatian dan prinsip syariah harus tetap diterapkan oleh agen.

\section{KESIMPULAN}

Program branchless banking pada perbankan syariah diharapkan mampu meningkatkan marketshare, sehingga dapat lebih berperan aktifmemajukan kesejahteraan masyarakat. Dalam pengembangan branchless banking, perbankan syariah dituntut untuk lebih fokus pada kelompok UMKM, kelompok mikro dan unbanked people sehingga dibutuhkan inovasi produk tabungan dan pembiayaan yang dapat dijangkau oleh mereka. Perbankan syariah juga harus memiliki kemampuan melakukan mitigasi risiko pembiayaan dan risiko operasional dengan memanfaatkan kearifan lokal yang ada di masyarakat.

Nilai-nilai lokal yang dipahami oleh perbankan syariah dapat menjadi keuntungan dalam mengembangkan branchless banking. Perbankan syariah harus memiliki kemampuan untuk bekerjasama dengan unit ekonomi lokal. Kemampuan mengembangkan inovasi produk keuangan, kemampuan membuat standar pelayanan nasabah yang disesuaikan dengan karakteristik kegiatan harian yang dilakukan masyarakat, dan jaringan distribusi yang disesuaikan dengan karakteristik masyarakat di setiap daerah menjadi kunci penting dalam pengembangan branchless banking perbankan syariah, sehingga dibutuhkan penguasaaan teknologi informasi.

\section{REKOMENDASI}

Pelaksanaan model branchless banking perbankan syariah dengan model keagenan membutuhkan kebijakan dan aturan yang jelas mengenai fungsi, tujuan, peran, hak dan kewajiban hukum agen dalam branchless banking perbankan syariah. Di perlukan sosialisasi, kegiatan promosi yang lebih sporadis tentang keuangan inklusif terkait dengan isu pengentasan kemiskinan, pertumbuhan market share bank syariah.

\section{DAFTAR PUSTAKA}

Anand, M. B., \& Sreenivas, D. L. (2013) “A Study on Branchless Banking in India," International Journal of Development Research, 3 (8): 001-006.

Ascarya. (2015). Design of Holistic Financial Inclusion Based on Maqashid Shariah. Diakses dari pubdocs.worldbank.org/pubdoc/P1-Dr-Ascarya.pdf. Diakses 1 Agustus 2017

Bank Indonesia. (2014). Booklet Keuangan Inklusif. Departemen Pengembangan Akses Keuangan dan UMKM: Bank Indonesia, 6-8.

Collings, G. (2011). How Over-regulation has Stifled the Pace of Mobile Money Adoption in Africa. Mobile Money Africa. Available at:http://mobilemoneyafrica.com/how-overregulation-has-stifled-the-pace-of-mobile-money-adoption-in-africa/. Diakses 1 Agustus 2017.

Dermish,A., Kneiding, C., Leishman, P., \& Mas, I. (2011). Branchless and Mobile Banking Solutions for the Poor: A Survey of Literature, Innovations. 6 (4), https://papers.ssrn.com/ sol3/papers.cfm?abstract_id $=1745967 \&$

Disha, B., Bapat, V., \& Bera, S. (2012). Studying Financial Inclution in Nort-East India, International Journal of Bank Marketing Emerald Insight: 246-256.

Fielnanda, R., (2016). Analisis Kesiapan Penerapan Branchless Banking Bank Syariah dengan 
Pendekatan Analytic Network Process BOCR (ANP BOCR). Tesis Program Pascasarjana UIN Sunan Kalijaga: Yogjakarta.

Global Business Guide Indonesia. (2013). An Outlook on Indonesia's Microfinance Sector. http://www.gbgindonesia.com/en/finance/article/2013/an_outlook_on_Indonesia_s_ microfinance_sector.php. Di akses 16 Juli2017.

Herman, S. (2015). Negara Mayoritas Muslim, Mengapa Pangsa Pasar Bank Syariah Rendah. Kumpulan Hasil Riset Terbaik Forum Riset Ekonomi dan Keuangan Syariah III, Depok. Paper dipresentasikan dalam acara Forum Riset Ekonomi dan Keuangan Syariah IV Universitas Brawijaya Malang, 3-4 November 2015, 5.

Hegde, S. \& Kotian, V.D. (2016). Branchless Banking for The Poor as a Part of Financial Inclution. International Journal of Scientific Research and Modern Education. 1 (2). dx.doi.org/10.5281/ZENODO.158938

Ivatury, G. (2006). Using Technology to Build Inclusive Financial Systems. Focus Note 32., Washington, DC: CGAP.

Blanco, J. et. al. (2014). Models and Barriers for Fianncial Inclusion. Financial Inclusion 2020CFI, diakses daari http://cfi-blog.org/2017/12/10/2017/models-and-barriers-for-financialinclution/on: 14-22.

Kamana, J. (2014). M-PESA: How Kenya Took the Lead in Mobile Money. http://www. mobiletransaction.org/m-pesa-kenya-the-lead-in-mobile-money/.

Kartiko, W. (2015). Strategic of Islamic Micro Finance (BMT) in Financial Inclusion Movement. Interview Result, on 12 July 2015, as Chief of Java BMT Association.

Khaldun, I. (1986). Muqaddimah Ibn Khaldun. Terjemahan Ahmadie Thoha. Jakarta: Pustaka Firdaus.

Leyshon, A., \& Thrift, N. (1995). Geographies of Financial Exclusion: Financial Abandonment in Britain and the United States. JSTOR. New Series, 20 (3): 312-241.

Lyman, T. R., Ivatury, G., \& Staschen, S. (2006). Use of Agents in Branchless Banking for the Poor: Rewards, risks and regulations. Focus note No.38. Washington DC. : CGAP.

Mas, I. (2009). The Economic of Branchless Banking. Majalah Innovations. 4 (2).

Mujahidin, A. (2016). Peranan Kearifan Lokal (Local Wisdom) dalam Pengembangan Ekonomi dan Perbankan Syariah di Indonesia. Jurnal Ilmiah Syariah, 15 (2), Juli-Desember

Mustafida, R, (2015). Branchless Banking: Menuju Peran Perbankan Syariah dalam Mencapai Financial Inclusion. Paper dipresentasikan dalam acara Forum Riset Ekonomi Syariah di Jakarta, 20 November 2015

Nyamtiga, B. W., Sam, A., \& Laizer, L. S. (2013). Enhanced Security Model for Mobile Banking Systems in Tanzania. International Journal Technology Enhancements and Emerging Engineering Research, 1(4):4-20.

Porteous, D. (2006). The Enabling Environment for Mobile Banking in Africa. Report prepared by Bankable Frontier Associates for DfID

Purboastuti, N., Anwar, N., \& Suryahani, I. (2015). Pengaruh Indikator Utama Perbankan terhadap Pangsa Pasar perbankan Syariah, Journal of Economic and Policy. JEJAK 8 (1). 13-22, doi: http://dx.doi.org/10.15294/jejak.v8i1.3850

Purwati, Y., Franksiska, R., \& Nugroho, P., I. (2014). Strategi Peningkatan Kemampuan Adopsi Tekhnologi Branchless Banking untuk Memperluas Inklusi Keuangan di Masyarakat Pedesaan, Publikasi Ilmiah UMS Seminar Nasional dan Call for Paper (Sancall 2014): Research Methods and Organizational Studi, 205..

Rijanto, E. (2016). Kajian Potensi Keuangan Unbanked People pada berbagai Sektor. www.bi.go. id diakses tanggal 26 Juli 2017.

Sankaramuthukumar, S., \& Alamelu, K. (2012). Financial Inclusion: African Scenario”. Insight on Africa Journal. Sage UK: London, England SAGE Publications, 4 (2), 121-135.

Santoso, B., \& Ahmad, K. (2016). Islamic Microfinance Branchless Banking Model in Indonesia. 
Intelectual Discourse, Special Issue: 409-433.

Santoso, B. (2015). Financial Inclusion Model for Indonesia. ICOSOPP. Aceh.

Sarah, H. (2015). Dampak Branchless Banking terhadap Kinerja Keuangan PT. Bank Muamalat Indonesia Tbk. Al-Muzaraah: Journal of Islamic Economics and Finance. 3 (2). http:// dx.doi.org/10.29244/jam.3.2.136-157.

Syaltut, M. (1959). Akidah wa al-Syari'ah. Beirut: Dar al-Fikri. Cet ke-1.

Syeda, S. A., et. Al. (2015). Quality of Branchless Banking Service in Lahore City: Application of Servequal Model. Sci.Int (Lahore). 1490-1502.

Wibowo, P. P. (2013). Branchless banking Setelah Multilicense: Ancaman atau Kesempatan Bagi Perbankan Nasional. Disampaikan dalam rangka Memenuhi Salah Satu Persyaratan Sekolah Staff Pimpinan Bank indonesia (SESPIBI) Angkatan XXXI, www.bi.go.id diakses 15 Agustus 2017.

Yesi, H. S., \& Kasmiati. (2013). Branchless Banking Mewujudkan Keuangan Inklusif sebagai Alternatif Solusi Inovatif Menanggulangi Kemiskinan: Review \& Rekomendasi, Program Magister Sekolah Pascasarjana Institut Pertanian Bogor, unpublished paper, IPB Press, bogor, pp. 78-82

\section{Internet:}

www.bi.go.id

www.cpga.org

www.infobanknews.com

www.ojk.go.id 